\title{
Correlation between Pelvic Organ Prolapse Symptoms and Age of Menopause
}

\author{
Rizqy Rahmatyah', Gatut Hardiyanto ${ }^{2}$, Dwi Susanti ${ }^{3}$ \\ 'Medical Doctor Program, ${ }^{2}$ Obstetry and Gynecology Department, ${ }^{3}$ Public Health and Preventive Medicine \\ Department, Faculty of Medicine, Airlangga University, Surabaya, Indonesia
}

\begin{abstract}
ABSTRAK
Tujuan: Penelitian ini bertujuan untuk mengetahui karakteristik pasien dengan gejala POP di Klinik Rawat Jalan Geriatrik Rumah Sakit Umum Dr. Soetomo.

Bahan dan Metode: Penelitian ini merupakan penelitian observasional analitik dengan teknik cross-sectional dan purposive sampling. Populasi dalam penelitian ini adalah pasien di Klinik Rawat Jalan Geriatrik Rumah Sakit Umum Dr. Soetomo. Kuesioner digunakan untuk mengumpulkan data dan SPSS 21.0 digunakan untuk analisis. 56 pasien menjadi subyek dalam penelitian ini. Data dianalisis dengan uji chi-square, MannWhitney dan Spearman's rho menggunakan SPSS 21.0.

Hasil : Data yang didapat adalah 13 responden $(23,2 \%)$ memiliki gejala POP berdasarkan POPDI-6, dengan skor tertinggi 45,8 (cutoff 75). Hubungan yang signifikan ditemukan pada hubungan usia menopause dengan gejala berkemih yang tidak tuntas $(p=0,036)$. Ini juga merupakan faktor risiko gejala tonjolan vagina pada pasien di Poli Geriatri Rumah Sakit Umum Dr. Soetomo. (MOG 2017;25:30-32)
\end{abstract}

Kata kunci: Proplaps Organ Pelvis, POPDI-6, Menopause yang terlambat, Geriatric

\begin{abstract}
Objectives: This study aims to determine the characteristics of patients with POP symptoms in Geriatrics Outpatient Clinic Dr. Soetomo General Hospital.

Materials and Methods: This is an analytic observational research with cross-sectional and purposive sampling techniques. The population in this study were patient in Geriatrics Outpatient Clinic Dr. Soetomo General Hospital. Questionnaire was used to collect data and SPSS 21.0 was used for the analysis. 56 patients became subjects in this study. Data were analyzed by chi-square test, Mann-Whitney and Spearman's rho using SPSS 21.0.

Results: Data obtained was 13 respondents $(23.2 \%)$ had symptoms of POP based POPDI-6, with the highest scores of 45.8 (cut-off 75). A significant association was found in the association of menopausal age with symptoms of incomplete voiding ( $\mathrm{p}=$ 0.036). It is also a risk factor for symptoms of vaginal bulge in patients at Geriatrics Outpatient Clinic Dr. Soetomo General Hospital. (MOG 2017;25:30-32)
\end{abstract}

Keywords: Pelvic Organ Prolapse, POPDI-6, Late Menopause, Geriatric

Correspondence: Rizqy Rahmatyah, Undergraduate Student of Faculty of Medicine, Airlangga University

\section{INTRODUCTION}

Increasing life expectancy in Indonesia in recent years force health care to keep up with the development of existing diseases abnormalities. One of the abnormalities that become prima donna among postmenopausal women is pelvic organ prolapse (POP), an abnormalities that arise as a result or herniation of the pelvic organs include uterine prolapse, apical vaginal prolapse, cystocele, or rectocele. ${ }^{1}$ In the United States more than 225,000 patients with POP diagnoses underwent surgery procedures during $1997 .^{2}$ While in the United Kingdom, $20 \%$ of women who were enrolled in the list of gynecological surgeries were diagnosed with POP. ${ }^{3}$

Menopause causes decreasement of collagen in female's body which can cause weakening of pelvic floor that correlates positively to the incidence of POP. ${ }^{4}$ The culture of Indonesian people results in the absence of signs and symptoms of POP in elderly women and if they feel uncomfortable, they do not know that their complaints can be furtherly investigated or to whom they should come with their complaints. This study aims to determine the relationship between symptoms of menopause with signs of symptoms of POP in Geriatric Outpatient Clinic Dr. Soetomo General Hospital.

\section{MATERIALS AND METHODS}

This research is an observational analytic research with cross-sectional research design. The research was conducted on August 2016 at Geriatric Outpatient Clinic Dr. Soetomo General Hospital. The study population was all female patients who came Geriatric Outpatient Clinic Dr. Soetomo General Hospital. The sample was taken based on purposive sampling towards all women who came in August 2016 and fulfilled the inclusion criteria. The inclusion criteria in this study were age of $>60$ years old and willingness to be interviewed, while the exclusion criteria are the history of ehlerr syndrome and connective tissue abnormalities, as well as pelvical trauma or injury. The type of data obtained is primary data using demographic questionnaire and Pelvic Organ Prolapse Distress Inventory-6 (POPDI-6) questionnaire. 


\section{RESULTS AND DISCUSSION}

This study was conducted on August 2016. Total female patients in Geriatric Outpatient Clinic Dr. Soetomo General Hospital at that day was 172 patients. The minimum expected number of samples is 161, but patients who met the inclusion criteria of the existing population were only 56 .

A total of 23 respondents (50\%) had menopausal age $\leq$ 49 years and 23 respondents $(50 \%)$ at age 250 years. Minimum menopause age is 6 years and maximum 44 years. The average has been experiencing menopause for $24( \pm 8.63)$ years. The distribution of kurtosis shows the value of -0.115 which indicates that the respondent's data in this study is normal.

Most respondents did not have POP symptoms based on the answers according to the POPDI-6 questionnaire. As many as 13 respondents (23.2\%) claimed to have symptoms of POP with the highest value range of 45.8 , this figure is still below the cut off of POPDI-6 that is 75 so that the screening results don't explicitly state that the subjects suffered from POP. Based on the points in the questionnaire, 12 respondents $(21.4 \%)$ had defecation difficulties and 10 respondents $(17.9 \%)$ had unexplained urination symptoms. While the symptoms of lower abdominal pressure and protrusion of the vagina were each found in 3 respondents $(5.4 \%)$

Table 1. Research subjects characterictics

\begin{tabular}{|c|c|c|}
\hline Subjects' Characteristics & $\mathrm{n}$ & $\%$ \\
\hline \multicolumn{3}{|l|}{ Age (years old) } \\
\hline $60-69$ & 18 & 32.1 \\
\hline $70-79$ & 27 & 48.2 \\
\hline $80-89$ & 11 & 19.6 \\
\hline \multicolumn{3}{|l|}{ Job } \\
\hline Housewives & 29 & 51.8 \\
\hline Retired teachers & 7 & 12.5 \\
\hline Retired hospital employee & 11 & 19.6 \\
\hline Self-employed & 4 & 7.1 \\
\hline Others & 5 & 8.9 \\
\hline \multicolumn{3}{|l|}{ Age of Menopause (years old) } \\
\hline$\leq 49$ & 28 & 50 \\
\hline$\geq 50$ & 28 & 50 \\
\hline \multicolumn{3}{|l|}{ Length of Menopause (years) } \\
\hline $1-10$ & 5 & 8.9 \\
\hline $11-20$ & 11 & 19.6 \\
\hline $21-30$ & 29 & 51.8 \\
\hline $31-40$ & 9 & 16.2 \\
\hline$>40$ & 2 & 3.6 \\
\hline \multicolumn{3}{|l|}{ Parity Numbers } \\
\hline $0-1$ & 5 & 8.9 \\
\hline $2-4$ & 34 & 60.7 \\
\hline 25 & 17 & 30.4 \\
\hline \multicolumn{3}{|l|}{ Pervaginam Delivery History } \\
\hline $0-2$ & 18 & 32.1 \\
\hline 23 & 38 & 67.9 \\
\hline Body Mass Index & & \\
\hline
\end{tabular}

\begin{tabular}{lll} 
Underweight $(<18.50)$ & 8 & 14.3 \\
Normal $(18.50-24.99)$ & 30 & 53.6 \\
Overweight $(25-29.99)$ & 12 & 21.4 \\
Obesity $(\geq 30)$ & 6 & 10.7 \\
Smoking History & & \\
$\quad$ Yes & 0 & 0 \\
$\quad$ No & 56 & 100 \\
Alchohol Consumption History & & \\
$\quad$ Yes & 1 & 1.8 \\
No & 55 & 98.2 \\
POPDI-6 Score & & \\
$<75$ & 56 & 100 \\
$>75$ & 0 & 0 \\
\hline
\end{tabular}

The starting age of menopause is a risk factor that has a significant association with the uncomplete voiding feelings of POP symptoms. This result is supported by the study done by Reay JNH and colleagues ${ }^{7}$ which suggests that there is a significant relationship between decreased uterosacral ligament resistance and menopause.

The starting age of menopause was significantly associated $(\mathrm{p}=0.036)$ with POP symptoms. Odd Ratio of 5.20 with 95\% Confidence Interval of 0.993-27.266 indicates that patients who start having menopause in $>50$ years old have a possibility to experience uncomplete voiding (odd) 5.2 times higher than general population. This may be related to an increase in postmenopausal estrogen.

Gold $\mathrm{EB}^{8}$ adds in his research that women with older starting age of menopause have tendencies to have higher life expectancy with lower levels of osteoporosis and cardiovascular disease. This is contrary to the results obtained in this study that women with younger starting age of menopause have protective factor against the incidence of incomplete voiding.

The incidence of prolapse in this study may not only due to the starting age factor of menopause but also by other risk factors because the existing confounding factors cannot be controlled optimally. The results of this study only shows the incidence of POP in Geriatric Outpatient Clinic Dr. Soetomo General Hospital, Surabaya, and has not described the incident that occurred in wider community.

\section{CONCLUSION}

There is a relationship between the starting age of menopause with symptoms of POP, which is uncomplete voiding and bowel emptying. 
Table 2. Scoring percentage of each question in POPDI-6

\begin{tabular}{|c|c|c|c|c|c|}
\hline \multirow[b]{2}{*}{ Symptoms } & \multirow{2}{*}{$\begin{array}{c}\text { Not } \\
\text { present } \\
(0) \\
\mathrm{N}(\%)\end{array}$} & \multicolumn{4}{|c|}{$\begin{array}{l}\text { Yes } \\
\mathrm{N}(\%)\end{array}$} \\
\hline & & $\begin{array}{l}\text { Not at all (1) } \\
\quad \mathrm{N}(\%)\end{array}$ & $\begin{array}{c}\text { Somewhat } \\
(2) \\
\mathrm{N}(\%) \\
\end{array}$ & $\begin{array}{c}\text { Moderately } \\
\text { (3) } \\
\mathrm{N}(\%) \\
\end{array}$ & $\begin{array}{c}\text { Quite a bit } \\
\quad(4) \\
\mathrm{N}(\%) \\
\end{array}$ \\
\hline \multirow[b]{2}{*}{ Pressure in the lower abdomen } & \multirow[b]{2}{*}{$53(94.6)$} & \multicolumn{4}{|c|}{$3(5.4)$} \\
\hline & & $1(1.8)$ & $0(0)$ & $1(1.8)$ & $1(1.8)$ \\
\hline \multirow{2}{*}{ Heaviness in pelvic area } & \multirow{2}{*}{$55(98.2)$} & \multicolumn{4}{|c|}{$1(1.8)$} \\
\hline & & $0(0)$ & $0(0)$ & $0(0)$ & $1(1.8)$ \\
\hline \multirow{2}{*}{ Buldge falling out from vagina } & \multirow{2}{*}{$53(94.6)$} & \multicolumn{4}{|c|}{$3(5.4)$} \\
\hline & & $1(1.8)$ & $0(0)$ & $1(1.8)$ & $1(1.8)$ \\
\hline \multirow{2}{*}{ Uncomplete bowel emptying } & $44(78.6)$ & \multicolumn{4}{|c|}{$12(21.4)$} \\
\hline & $46(82.1)$ & $2(3.6)$ & $\begin{array}{l}2(3.6) \\
10\end{array}$ & $0(0)$ & 4.3) \\
\hline \multirow[b]{2}{*}{ Have to push up buldge in vagina } & \multirow[b]{2}{*}{$55(98.2)$} & $3(5.4)$ & $4(7.1)$ & $0(0)$ & $3(5.4)$ \\
\hline & & \multicolumn{4}{|c|}{$1(1.8)$} \\
\hline
\end{tabular}

Table 3. Analysis of starting ages of menopause with POPDI-6 Symptoms

\begin{tabular}{|c|c|c|c|c|c|c|c|c|c|c|}
\hline & & & \multicolumn{8}{|c|}{ POPDI Symptoms } \\
\hline & & & \multicolumn{2}{|c|}{ Vaginal buldging } & \multicolumn{2}{|c|}{$\begin{array}{l}\text { Uncomplete bowel } \\
\text { emptying }\end{array}$} & \multicolumn{2}{|c|}{ Uncomplete voiding } & \multicolumn{2}{|c|}{ Pressure in lower abdomer } \\
\hline \multicolumn{3}{|c|}{ Starting Ages of Menopause } & $\$ 49$ & 250 & $\leq 49$ & 250 & $\leq 49$ & 250 & $\leq 49$ & 250 \\
\hline \multirow{2}{*}{ Symptoms } & No & $\mathrm{n}(\%)$ & $27(50.9)$ & $26(49.1)$ & $23(82.1)$ & $21(75.0)$ & $26(92.9)$ & $20(71.4)$ & $28(100)$ & $0(0)$ \\
\hline & Yes & $\mathrm{n}(\%)$ & $1(33.3)$ & $2(66.7)$ & $5(17.9)$ & $7(25.0)$ & $2(7.1)$ & $8(28.6)$ & $25(89.3)$ & $3(10.7)$ \\
\hline $\mathrm{r}$ & & & \multicolumn{2}{|c|}{2.077} & \multicolumn{2}{|c|}{1.533} & \multicolumn{2}{|c|}{5.20} & \multicolumn{2}{|c|}{ Nill } \\
\hline$P$ value & & & \multicolumn{2}{|c|}{$0.5^{* *}$} & \multicolumn{2}{|c|}{$0.515^{* *}$} & \multicolumn{2}{|c|}{$0.036^{* *}$} & \multicolumn{2}{|c|}{$0.236^{* *}$} \\
\hline $\begin{array}{l}\text { 95\% Confidence } \\
\text { Interval } \\
\end{array}$ & $\begin{array}{l}\text { Upper - } \\
\text { Lower }\end{array}$ & & \multicolumn{2}{|c|}{$(0.177-24.313)$} & \multicolumn{2}{|c|}{$(0.422-5.577)$} & \multicolumn{2}{|c|}{$(0.993-27.226)$} & \multicolumn{2}{|c|}{ Nill } \\
\hline
\end{tabular}

\section{REFERENCES}

1. Lazarou G [internet]. Pelvic Organ Prolapse [updated 2010; cited 2015 Aug 13]. Available from: http://emedicine.medscape.com/article/276259overview. Diakses pada 13 Agustus 2015.

2. Subramanian D, Szwarcensztein K, Mauskopf JA, Slack MC. Rate, type, and cost of pelvic organ prolapse surgery in Germany, France, and England. European Journal of Obstetrics \& Gynecology and Reproductive Biology 2009;144-80, 177-181.

3. Jelovsek JE, Maher C, Barber MD. Pelvic Organ Prolapse. Lancet 2007;369:1027-38.

4. Purwara BH, Armawan E, Sasotya RMS, Achmad ED. Faktor risiko penderita prolapsus organ panggul terhadap hiatus genitalis, panjang total vagina, dan perineal body. Majalah Kedokteran Bandung 2014;64-1:57-60
5. Barber MD, Kuchibhatla MN, Pieper CF, Bump RC. Psychometric evaluation of 2 comprehensive condition-specific quality of life instruments for women with pelvic floor disorders. Am J Obstet Gynecol. 2001;185:1388-95.

6. Barber MD, Walters MD, Bump RC. Short forms of two condition-specific quality-of-life questionnaires for women with pelvic floor disorders (PFDI-20 and PFIQ-7). Am J Obstet Gynecol. 2001;193:103-13.

7. Reay JNH, Healy JC, King LJ, et al. Pelvic connective tissue resilience decrease with vaginal delivery, menopause and uterine prolapse. British Journal of Surgery 2003;90(4):466-72.

8. Gold EB. The timing of the age at which natural menopause occurs. Obstetrics and Gynecology Clinics of North America 2011;38(3):425-440. doi:10.1016/j.ogc.2011.05.002. 